\title{
ROLE OF LIQUIDITY AND PROFITABILITY OF SHARIA BANK ON INDONESIAN ECONOMIC GROWTH
}

\author{
Iwan Setiawan $^{1 *}$, Teti Sofia Yanti ${ }^{2}$ \\ ${ }^{1}$ Department of Accounting, Politeknik Negeri Bandung \\ ${ }^{2}$ Department of Statistics, Universitas Islam Bandung \\ *1 iwan.setiawan@polban.ac.id \\ ${ }^{2}$ tetisofiayanti@unisba.ac.id
}

\begin{abstract}
This research aims to find out the factors that determine liquidity and profitability as well as the contribution of Sharia banking to the economic growth in Indonesia. The study used quarterly data for the period 2009-2019, a multiple regression model with the Ordinary Least Square (OLS) analysis method. The results revealed that capital, financing and third party funds are factors that determine the liquidity of Sharia banking. Sharia banking profitability is influenced by capital and inflation. The role of Sharia banking on economic growth occurs through financing activities, large capital and utilization of Sharia monetary policy instruments. Efforts to control liquidity at optimal levels can be done by taking into account the capital factors held by Sharia banking. Efforts to achieve maximum value of profitability can be implemented by benefiting price stability in the macroeconomic. Efforts to boost economic growth are carried out by utilizing rising prices and limiting the profit value of Sharia monetary policy instruments. Moreover, Sharia banking is able to increase the share of financing channeled.
\end{abstract}

Keywords: Liquidity; Rentability; economic growth

*Correspondent author

\section{Introduction}

Sharia banks have contributed to the economic development in Indonesia. Sharia banks play a role in the process of creating low inflation in Indonesia (Ascarya, 2014), and Sharia bank financing plays a role in increasing economic growth and job creation in almost all sectors (Setiawan, 2019). Murabahah financing of Sharia banks provides positive contributions to the economic development of the agricultural sector (Khotijah \& Iswanaji, 2020). The contribution of Sharia banks to the economy cannot be separated from the internal condition of Sharia banks, one of which is the liquidity condition of banks.

Liquidity contributes positively to the value of banks although there is a trade off between efforts to increase liquidity and efforts to strengthen profitability and 
solvency (Berger \& Sedunov, 2017). The creation of high liquidity adversely affects the solvency of banks (Horvarth, et al., 2012) Increased liquidity has an impact on the declining profitability of Islamic banks (Sahyuni \& Wang, 2019). The importance and complex liquidity management of banks can be the main cause of decline in bank's profit (Noegroho, 2014).

Sharia banks have a higher liquidity risk than conventional banks (Mohammad, 2014). The efficiency and profitability of Sharia banks is lower than conventional banks and stagnating in growth (Halit \& Pabuccu, 2017). Banks raise funds and channel into various financings. The more financing the greater its contribution to economic growth. Efforts to achieve profit through increased financing ratio resulted in decreased liquidity of banks (Ichwan \& Nafik, 2016).

Sharia bank's financing is growing rapidly with a growth of $34.84 \%$ per year, higher than the growth of conventional bank's loans (17.40\%). The increase in Sharia bank's financing is not in line with the profits obtained. The profit rate of Sharia bank is only at $1.36 \%$ per year, fluctuating and experiencing a downward trend with a decrease rate of 0.03 per year (Figure 1). Despite increase in financing, Sharia banks are experiencing excess liquidity. Sharia banks have not been able to optimize the distribution of third party funds into productive financing. The value of the ratio of financing to public deposits (FDR) decreased by $1.64 \%$ per year.

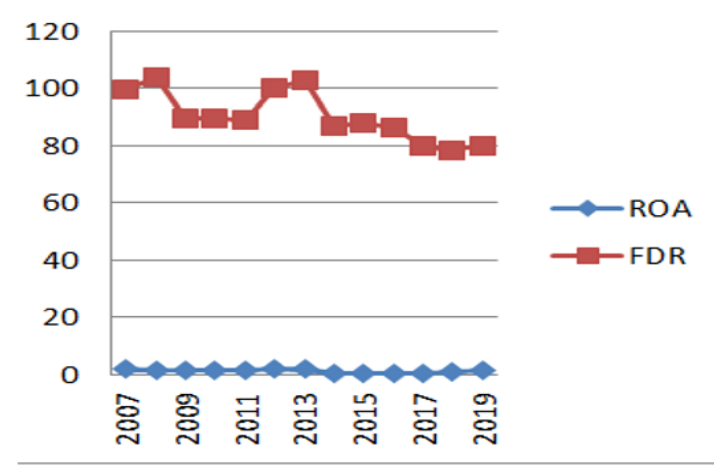

Source ; OJK, BI and BPS (processed)

Figure 1

Development of GDP, Credit, Financing, Liquidity and Rentability of Sharia Banking in Indonesia (in \%)

The government plays a role in managing liquidity to support the improvement of bank performance.
Government intervention in capital has an impact on decreasing bank liquidity risks and long-term economic developments 
(Berger et al., 2011). Liquidity management and renewal of Islamic financial institutions are in line with the process of sustainable development and financial stability (Aassouli et al., 2018). Sharia banking has great potential to develop and contribute positively to economic development. Sharia banks in Indonesia face constraints on the allocation of funds from third parties that are not optimal, less efficient and excess liquidity so that it is estimated to have an impact on decreasing rentability. This condition is projected to affect the declining performance of Sharia banks and their contribution to economic growth. The purpose of this research is to find out what factors determine the liquidity and profitability conditions of Sharia banking and how Sharia banking contributes to the Indonesia's economic growth.

\section{Discussion}

\section{A. Literature Review}

\section{Bank Liquidity and its Affecting Factors}

Bank liquidity is something unique, therefore it must be managed carefully so as not to cause other problems. Liquidity is defined as an overview of a financial institution's ability to meet short-term obligations without causing tolerable losses (Mars, 2008). Liquidity management describes the efforts of management to reduce the emergence of liquidity risks. Sources of liquidity can come from various sources of assets, one of which is from loans. Banks can increase liquidity through the flow of funds from loan portfolios. In the long run, banks can use loans to deal with liquidity crises. Loans can be sold on the secondary market to obtain the required cash (Alshatti, 2014).

Bank liquidity is determined by various factors, both internal and external. Liquidity risk management in Sharia banks depends on internal variables, banking industry and macro-economics (Rashid et al., 2017). Real economic growth has a positive effect on the creation of bank liquidity (Ichwan \& Nafik, 2016). GDP has the least impact, and inflation has the greatest impact on bank liquidity (Trenca et al., 2015). Policy integration from the government and bank management is required to reduce liquidity risk.

The reduction of liquidity risk is carried out through the application of capital rules for banks. Capital is important for banks although it does not guarantee that banks can survive the crisis (Berger et al., 2011). The experience of the 2008 crisis shows that strong capital does not guarantee banks survival. The difficulties faced by most banks are caused by the inability to meet the basic principles of measurement and application of liquidity risk 
management (Handayani \& Abubakar, 2018). Failure in managing liquidity risks causes an impact on decreasing liquidity levels and economic activity. Regulatory intervention has a significant effect on economic conditions. Capital support has a significant impact on economic conditions in the long term.

The level of profit (ROA) and nonperforming financing (NPF) played a positive role in increasing Sharia bank liquidity. The capital aspect (CAR) shows a negative and significant relationship with liquidity risk at Indonesian conventional bank (Sukmana \& Suryaningtyas, 2016). In Sharia banks, capital aspects (CAR) have a significant positive effect on liquidity risk, while ROA shows negative and significant results. In the short term, capital variables (CAR), profit (ROA), inflation and SBI interest rates have a positive and significant effect on the liquidity (FDR) of Sharia banks. In the long term, capital and inflation have a positive effect, while profits negatively affect liquidity (Faturrahman \& Rusdi, 2019). Profitability has a negative relationship with capital, but it has a positive relationship with liquidity risk in Sharia bank (Amran et al., 2017).

\section{Liquidity, Profitability and Economic Growth}

Good liquidity management can help banks improve profitability. One study revealed that poor liquidity management contributed negatively to performance (Ibe, 2013). The results of a different study from Lukorito, et al (2014) reveal that liquidity makes a positive contribution to bank's profitability. This study recommends that banks should have the best asset portfolios, invest aggressively, including holding short-term securities to support liquidity which will increase bank profits.

The quality of capital, assets and liquidity has no effect on the profitability condition of the banks (Ningsih et al., 2017). Bank's liquidity has only a significant effect on the value of the bank's assets and return on capital (Bassey \& Moses, 2015). Sharia banks have different balance sheets with conventional banks, resulting in different implications for the formation of liquidity. The regression results revealed a negative and significant relationship between liquidity levels and bank performance (ROA), both in Sharia banks and conventional banks (Sahyuni \& Wang, 2019).

To maintain an ideal liquidity position, banks must maintain the withdrawal of third party funds and maintain available financing requests (Zaini, 2016). There is a trade-off between liquidity and profitability. The relationship between liquidity and profitability is not too strong, and changes in liquidity have a small 
impact on changes in the profitability of Islamic banks in Indonesia (Notoatmojo, 2018). Sharia banks are experiencing excess liquidity problems.

Sharia Banks can utilize financial instruments such as Bank Indonesia Sharia Certificates (BIS) and Sharia Money Markets (PUAS) as a means to manage liquidity. The results reveal that the financial instruments available at Islamic banks have not been able to answer the problem of idle fund due to excess liquidity (Noegroho, 2014). Sharia banking efforts to optimize liquidity can be done through a combination of liability management and asset management. The balance of assets and liabilities is achieved by Islamic banks by regulating the time and amount of funds in terms of liabilities and assets (Ismal, 2010).

Sharia bank liquidity problems are anticipated by utilizing liquid instruments on the financial market. The use of these instruments is sufficient to assist Sharia banks in anticipating sudden and unexpected withdrawals of liquidity. Sharia bank liquidity is more risky due to the nature of the product, financial activity and very limited access to money market instruments (Dusuki, 2007). However, financial market instruments based on interest rates are not accessible to Sharia banks. Access to financial market instruments is one of the biggest obstacles and constraints in managing the liquidity of Sharia banks.

After financial crisis in 2008, liquidity risk management is urgently needed to anticipate the collapse of the banking and financial system in the country, including Indonesia. Insufficient liquidity led to the collapse of banks and the instability of the financial system as a whole. The creation of bank liquidity affects bank assets and output as well as real economic output (Berger \& Sedunov, 2017).

One of the efforts to optimize the role of liquidity in improving financial performance and economic growth is through the use of green financial instruments. The application of green financial instruments is recommended in the management of the liquidity of Sharia financial institutions. This instrument is relevant for financial stability and economic development and can increase investor attractiveness (Aassouli et al., 2018).

Studies from Tabash (2019) and Ledhem \& Mekidiche (2020) reveal that there is a positive relationship between the performance (profitability) of Sharia banks and economic growth. Sharia banks through improved performance can make a positive contribution to economic growth. This study provides support for efforts to 
encourage the development of Sharia banks as one of the efforts to encourage economic growth.
Referring to the purpose and results of the literature study, the research process is carried out by referring to the following framework.

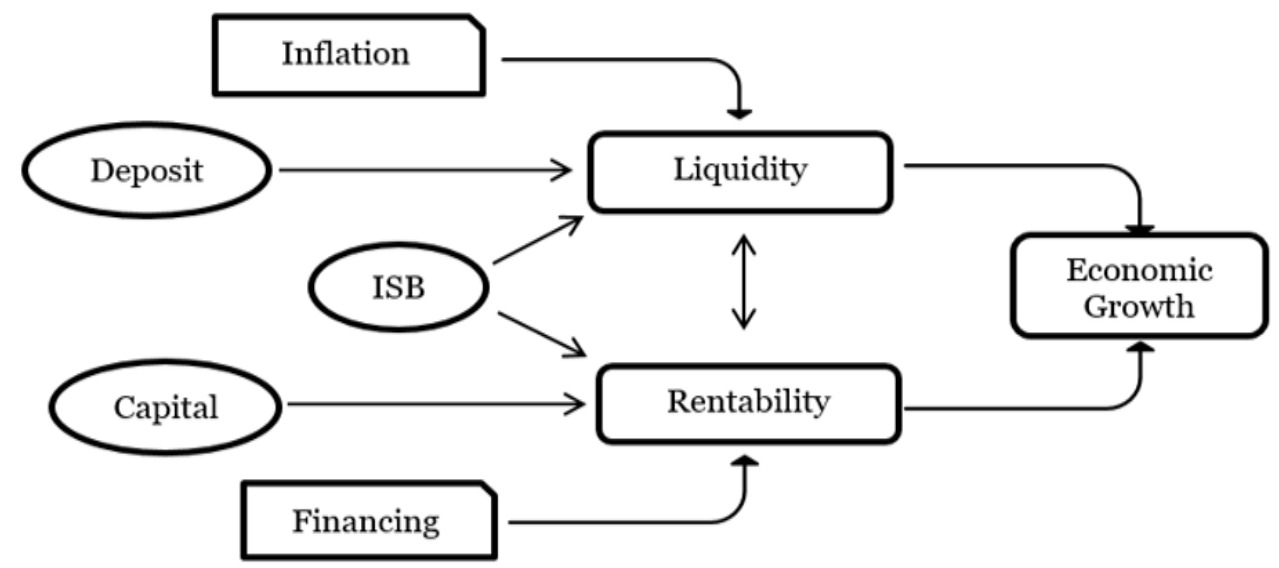

Source; processed products

Figure 2

Research Thought Framework

\section{B. Research Methods}

The object of this research is the Sharia banking industry in Indonesia. This research was conducted using 44 observational data for the quarterly period from 2009 to 2019. The data was obtained through literature methods and computerized methods. All data was obtained from the publication/web site of Bank Indonesia, the Central Bureau of Statistics and the Financial Services Authority. The analysis method used is qualitative and quantitative analysis method. This research analysis model uses Ordinary Least Square (OLS) estimation techniques. This analysis model is relevant for social researches that try to see, measure and test relationships between variables.

Structural equations of this research model are presented as follows;

$$
\begin{aligned}
& \operatorname{Lkd}_{t}=\alpha_{0}+\alpha_{1} \operatorname{Dep}_{t}+\alpha_{2} \operatorname{Cap}_{t}+ \\
& \alpha_{3} \text { Fin }_{t}+\quad \alpha_{4} \operatorname{Ins}_{t}+\alpha_{5} \text { Cpi }_{t}+ \\
& \alpha_{6} R n t_{t}+\varepsilon_{1} \\
& R n t_{t}=\beta_{0}+\beta_{1} \operatorname{Dep}_{t}+\beta_{2} \operatorname{Cap}_{t}+ \\
& \beta_{3} \text { Fin }_{t}+\quad \beta_{4} \text { Ins }_{t}+\beta_{5} C p i_{t}+ \\
& \beta_{6} L k d_{t}+\varepsilon_{2}
\end{aligned}
$$

Where:

Lkd = Sharia Bank Liquidity 
Rnt $=$ Sharia Bank Rentability

Grw $=$ Economic growth

Dep $=$ Third party funds in Sharia banking

Cap $=$ Capital in Sharia banks

Fin $=$ Sharia bank financing

Ins = Bank Indonesia Sharia Certificate

Instrument

Cpi $=$ Consumer Price Index

All equations are assumed to have a linear relationship and meet the requirements of the linear regression model. In the research model, various tests will be carried out. The design of the test conducted on the model of liquidity, rentability and economic growth is 1) The Goodness of Fit Test, to determine whether the model used is good or not, depending on: a) The coefficient of determination $\left(\mathrm{R}^{2}\right)$, which lies between zero and one. If the $\mathrm{R}^{2}$ value is getting closer to one, then the model used is quite good because the variation in changes of the dependent variable can be explained by variations in changes of the independent variable; $b$ ) The value of the F-test, is used to see the significance of the parameters of the independent variable on the dependent variable together. If the F-test is greater and than the F-table value, it can be said that the model used is good enough, because all the independent variables together can explain the dependent variable. 2) Parameter significance test, through t-test, is used to see whether the independent variable individually has a significant influence effect or not on the dependent variable. If the t-test value is greater and the t-table value is greater, it can be concluded that $\mathrm{H}_{0}$ is rejected, meaning that the independent variables individually have a significant effect on the dependent variable. 3) Econometric Testis to fulfill classical assumptions through: a. Autocorrelation test, to test the correlation between residual time series data at different points in time; b. Multicollinearity test, to ensure that the independent variables used in the model have no relationship; c. Heteroscedasticity test, to test the validity of the regression inference (error term), whether it has a constant variance for all levels of the independent variables; $d$. Normality test, to ascertain whether an estimated model is free from deviations from normality.

\section{Results and Discussion}

Based on data processing, the results of liquidity model, rentability model and economic growth model are presented in the following table: 
Table 1

Method: Least

Data Processing Results

Squares

Sample: 2009Q1 2019Q4

\begin{tabular}{|c|c|c|c|c|c|c|}
\hline \multirow{2}{*}{$\begin{array}{c}\text { Independent } \\
\text { Variable }\end{array}$} & \multicolumn{2}{|c|}{$\begin{array}{c}\text { Dependent Variable: } \\
\text { LKD }\end{array}$} & \multicolumn{2}{|c|}{$\begin{array}{c}\text { Dependent Variable: } \\
\text { RNT }\end{array}$} & \multicolumn{2}{|c|}{$\begin{array}{c}\text { Dependent Variable: } \\
\text { GRW }\end{array}$} \\
\hline & Coefficient & t-Statistic & Coefficient & t-Statistic & Coefficient & t-Statistic \\
\hline $\mathrm{C}$ & $-15625,32$ & $-0,238504$ & 18646,40 & $4,481580 *$ & 672832,1 & 1,836481 \\
\hline DEP & 1,098931 & $4,192819 *$ & 0,032084 & 1,307888 & $-2,046933$ & $-1,150725$ \\
\hline CAP & $-2,039314$ & $-2,187755^{*}$ & 0,207132 & $2,947805^{*}$ & 10,58458 & $\begin{array}{c}1,912138 * \\
*\end{array}$ \\
\hline FIN & $-0,818069$ & $-3,340207 *$ & 0,009123 & 0,415182 & 3,339019 & $2,138556^{*}$ \\
\hline INS & $-1287,595$ & $-0,735689$ & 75,93278 & 0,548650 & $-1,977862$ & $\begin{array}{c}- \\
2,007728 * \\
*\end{array}$ \\
\hline $\mathrm{CPI}$ & 288,0439 & 0,390311 & $-2,085618$ & $-4,424334 *$ & 9,057755 & $2,191933^{*}$ \\
\hline RNT & 1,221109 & 0,588208 & & & 13,98107 & 1,199619 \\
\hline LKD & & & 0,007587 & 0,588208 & 0,724951 & 0,789144 \\
\hline R-squared & \multicolumn{2}{|c|}{0,847068} & \multicolumn{2}{|c|}{0,813577} & \multicolumn{2}{|c|}{0,986878} \\
\hline $\begin{array}{l}\text { Adjusted R- } \\
\text { squared }\end{array}$ & \multicolumn{2}{|c|}{0,822269} & \multicolumn{2}{|c|}{0,783346} & \multicolumn{2}{|c|}{0,984326} \\
\hline F-statistic & \multicolumn{2}{|c|}{34,15639} & \multicolumn{2}{|c|}{26,91219} & \multicolumn{2}{|c|}{386,7691} \\
\hline Prob(F-statistic) & \multicolumn{2}{|c|}{$0,000000 *$} & \multicolumn{2}{|c|}{$0,000000 *$} & \multicolumn{2}{|c|}{$0,000000^{*}$} \\
\hline $\begin{array}{l}\text { Hannan-Quinn } \\
\text { criter. }\end{array}$ & \multicolumn{2}{|c|}{21,20104} & \multicolumn{2}{|c|}{16,11995} & \multicolumn{2}{|c|}{24,67536} \\
\hline $\begin{array}{c}\text { Durbin-Watson } \\
\text { stat }\end{array}$ & \multicolumn{2}{|c|}{1,335171} & \multicolumn{2}{|c|}{1,557290} & \multicolumn{2}{|c|}{1,347515} \\
\hline
\end{tabular}

significant of critical value *) $5 \% * *) 10 \%$

The estimated liquidity model shows the adjusted $\mathrm{R}^{2}$ value of 0.822269 , which is considered capable of explaining all changes in the independent variables to changes in dependent variables. Statistical F test results of 34.15639 show that all independent variable values together significantly affected dependent variables. Based on the results of the t-test, independent variables of third party funds (DEP), capital (CAR), financing in Sharia banks (FIN) have a significant influence on dependent variables (Sharia banking liquidity, LKD) and have signs in accordance with the specified hypothesis.

Rentability model estimated value shows adjusted $\mathrm{R}^{2}$ value of 0.783346 . This model is considered capable of explaining all changes in independent variables to changes in dependent variables. Statistical F test results of 26.91219 show that all independent variable values together significantly affect dependent variables. Based on the results of the $t$ test, the 
independent variable capital (CAR), and the inflation rate (CPI) exert a significant influence on rentability (RNT) and have a mark in accordance with the specified hypothesis.

The estimated economic growth model shows the determinant coefficient value (Adjusted $\mathrm{R}^{2}$ ) of 0.984326 , this model is considered capable of explaining all changes in independent variables to changes in dependent variables. Statistical F test results of 386.7691 show that all independent variable values together significantly affect dependent variables. Based on the results of the t-test, independent variable capital (CAR), Financing (FIN), Islamic monetary policy instruments (INS) and inflation rate (CPI) have a significant influence on economic growth (GRW) in Indonesia and have signs in accordance with the hypothesis specified. The $\mathrm{F}$ test and $\mathrm{t}$ test were conducted at a confidence level of $95 \%$ and 99\%. The Liquidity, Profitability and Growth model has met the classical assumptions. There is no correlation between the residual time series data, and the independent variables used in the model have no relationship. The error term has a constant variance for all levels of the independent variable and is free from deviations from normality.

In general, the relationships between significant variables in the Liquidity, Rentability and Economic Growth models are presented in Figure 3.

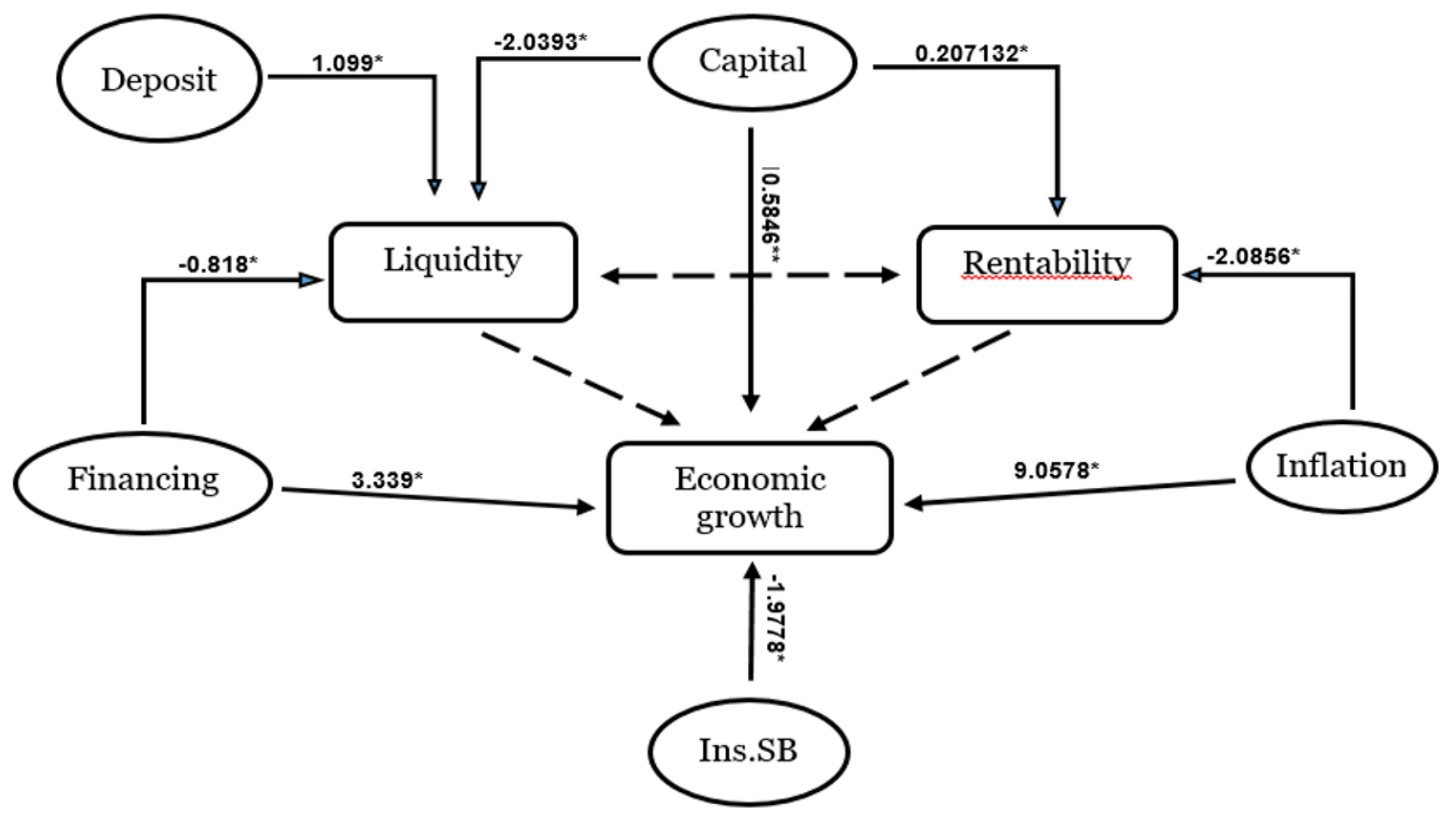

Description : Significant on critical value $*)=5 \%, * *)=10 \%$

Figure 3

Relationship Between Research Variables from

Liquidity, Rentability and Economic Growth Model 
Through the relationship between liquidity model variables, it was revealed that the increase in third party funds as well as the decrease in capital and financing resulted in increased liquidity in Sharia banking. The increasing function of raising funds from the public in the form of deposits will encourage increased liquidity in Sharia banks. On the other hand, the utilization of funds in financing and the increase in capital owned by banks resulted in reducing liquidity in Sharia banks. The increase in third party funds has a positive effect on Sharia banking liquidity. Each increase of $1 \%$ increase in third party funds results in a $1.09 \%$ increase in liquidity. The coefficient value shows a fairly balanced and significant change between the increase in funds raised from public deposits and the increase in liquidity in Sharia banking in Indonesia.

The increase in financing negatively affects Sharia banking liquidity. Each increase of $1 \%$ in financing resulted in a decrease in liquidity by $0.818 \%$. The coefficient value indicates a relatively small and significant change between the increase in financing and the decrease in liquidity in Sharia banking in Indonesia. The results of this study are in line with Ichwan \& Nafik (2016) and Zaini (2016). Efforts to maintain the bank's ideal liquidity position are carried out by maintaining the withdrawal of third party funds and maintaining the allocation of financing to Sharia banks.

The increase in capital negatively affects Sharia banking liquidity. Each increase of $1 \%$ in capital resulted in a decrease in liquidity by $2.039 \%$. The coefficient value indicates a considerable and significant change between an increase in owned capital and a decrease in liquidity in Sharia banking in Indonesia. The results of this study are in line with studies from Berger et al. (2011), which revealed that the reduction in liquidity risk is carried out through the application of capital rules for banks. This study is different from the results of studies from Sukmana \& Suryaningtyas (2016) and Faturrahman \& Rusdi (2019) which revealed that capital (CAR) has a significant positive effect on Sharia banking liquidity.

Through the relationship between variables in the Rentability model, it was revealed that lower inflation and increased capital amounts could increase the level of rentability in Sharia banking. Lower inflation will encourage increased rentability in Sharia banks. The results of this study are in line with the study of Amzal (2016), which reveals that inflation has an influence on the profits of Sharia 
banks. Efforts to reduce the inflation rate will have an impact on increasing the profits of Sharia banks.

The result of this study shows that inflation have a significant effect on Sharia banking rentability in Indonesia. The increase in inflation negatively affects Sharia banking rentability. Each increase of $1 \%$ in inflation resulted in a decrease in rentability of $2.086 \%$. The coefficient value indicates a considerable, elastic and significant change between the increase in inflation and the decrease in Rentability in Sharia banking in Indonesia.

The increase in capital has a positive effect on the increasing rentability of Islamic banking. Each increase of $1 \%$ in capital resulted in an increase in rentability of $0.207 \%$. The coefficient value indicates a small and significant change between the increase in owned capital and the increase in rentability in Sharia banking in Indonesia. The result of this study is in line with the study from Batten and Vinh (2019). Capital adequacy is one of the elements that has a strong influence on bank profitability. Efforts to increase profits cannot be separated from the ability of banks to provide capital.

Through the inter-variable relationship in the Economic Growth model, it was revealed that rising inflation, capital and financing as well as a decrease in the profits of Sharia monetary policy instruments have an effect on the increasing economic growth in Indonesia. Rising inflation will boost economic growth. Every $1 \%$ increase in inflation resulted in an increase in economic growth of $9.0578 \%$. The coefficient value indicates a large, elastic and significant change between rising inflation and economic growth in Indonesia. Inflation shows an increase in aggregate demand, thereby encouraging economic growth. The results of this study are different from the results of a study from Mandala (2020), which revealed a non-unidirectional relationship between inflation and economic growth in the long term. Price stability and reduced inflation are the keys to economic growth.

Increasing capital will encourage economic growth. Each increase of $1 \%$ in capital resulted in an increase in economic growth of $0.5846 \%$. The coefficient value indicates a small, in-elastic and significant change between capital raising and economic growth in Indonesia. This research is in line with the results of the study which revealed that government intervention in capital has an impact on decreasing bank liquidity risks and longterm economic development (Berger et al., 2011). Increasing the amount of capital shows the increase in financing that can be 
done by Sharia banks and an increase in the potential for economic growth.

Increasing financing will encourage economic growth. Each increase of $1 \%$ in financing in Sharia banking resulted in an increase in economic growth of 3.339\%. The coefficient value shows a considerable, elastic and significant change between the increase in financing and the occurrence of economic growth in Indonesia. The results of this study are in line with the results of the study by Ayyubi, et al (2017), which revealed that Sharia bank financing provides the biggest role in economic growth. Efficiency in the distribution of third party funds to support various financing programs is the key to the success of Sharia banking's role in economic growth.

The increasing level of profit from Sharia monetary policy instruments resulted in a decrease in economic growth. Every $1 \%$ increase in profits from Sharia monetary policy instruments resulted in a decrease in economic growth of $1.9778 \%$. The coefficient value indicates a considerable, elastic and significant change between the increase in the profit level of Sharia monetary policy instruments and the decline in economic growth in Indonesia. The result of this study is in line with the result of a study by Setiawan (2017) which reveals that Sharia monetary policy instruments play a role in Indonesia's longterm economic growth. The formulation of policies and the application of the right monetary policy instruments can help the central bank reaches the target of price stability and help the government to boost economic growth.

\section{Conclusion}

Referring to the purpose of the research, it can be conveyed that 1) Sharia banking liquidity is influenced by third party funds, capital and financing factors. The increase in the number of deposits in Sharia banks was followed by an increase in the amount of liquidity with a relatively comparable portion. The increase in capital and financing resulted in liquidity reduction in Sharia banks. The increase in capital will result in a decrease in the amount of liquidity with a considerable portion. The increase in financing will result in a decrease in the amount of liquidity with a relatively small portion; 2) Sharia banking rentability is influenced by capital and inflation factors. The increase in capital will have an impact on increasing rentability with a relatively small portion of the increase. The increase in inflation has an impact on the decrease in rentability with a considerable portion; 3) Economic growth in Indonesia is influenced by bank capital, Sharia bank financing, inflation rate 
and profit level in Sharia monetary policy instruments. By increasing bank capital, increasing financing and utilization of Sharia monetary instruments, Sharia banks can contribute to economic growth in Indonesia.

Related to the results of research and efforts to improve liquidity, rentability and economic growth, the following suggestions are proposed. 1) Efforts to maintain Sharia banking liquidity are carried out by always maintaining the capital by shareholders. The amount of capital adjusts to the target level of optimal liquidity, financing target and profit to be achieved by Sharia banks. 2) To achieve a high level of rentability, Sharia banks must ensure the stability or reduce inflation through various affordable financing incentive programs for Sharia banking customers. 3) To boost economic growth, the government can encourage increased financing in Sharia banking and reduce the profit value of Sharia monetary policy instruments. Rising prices (inflation) is also an opportunity to increase Indonesia's economic growth.

\section{Bibliography}

Aassouli, D., Ebrahim, M.-S., \& Basiruddin, R. (2018). Can Ugits Promote Liquidity Management And Sustainable Development? International Journal of Islamic Finance (ISRA), Vol. 10 No. 2,
2018, 126-142. Doi:10.1108/IJIF12-2017-0055

Alshatti, S. (2014). The Effect Of The Liquidity Management On Profitability In The Jordanian Commercial Banks. International Journal of Business And Management, Vol. 10, No. 1; 2015.

Amran, Nur Hazimah, \& Ahmad, W. (2017). Liquidity Risk: An Islamic Banking Perspective CPJIM\&A, Uitm Perlis The 2015 International Conference On The Future Of ASEAN (Icofa 2015) Special Issue 74. Jurnal Intelek (2017), Vol 12(1), ISSN 2231-7716(CPJIM\&A, Uitm Perlis The 2015 International Conference On The Future Of ASEAN (Icofa 2015) Special Issue 74).

Amzal, Cupian(2016), The Impact Of Macroeconomic Variables On Indonesia Islamic Banks Profitability, Jurnal Ekonomi dan Bisnis Islam, Vol. 2, No. 1, JanuariJuni 2016.

Ascarya. (2014). Monetary Policy Transmission Mechanism Under Dual Financial System In Indonesia; Interest-Profit Channel. International Journal of Economics Management And Accounting, 1-32.

Ayyubi, Salahuddin El, Lukytawati Anggraeni, dan Almira Dyah Mahiswari (2017), Pengaruh Bank Syariah Terhadap Pertumbuhan Ekonomi Di Indonesia, Jurnal AlMuzara'ah Vol. 5 No. 2, 2017 (ISSN P: 2337-6333) DOI: 10.29244/Jam.5.2.88-106

Bassey, G., \& Moses, C. (2015). Bank Profitability And Liquidity Management: A Case Study Of Selected Nigerian Deposit Money Banks. International Journal of Economics, Commerce And Management United Kingdom, Vol. III, Issue 4, April 2015. 
Batten, J., \& Vinh, X. V (2019. Determinants Of Bank Profitability-Evidence From Vietnam. Emerging Markets Finance And Trade, 55(6), 2019. 1417-1428.

Doi:10.1080/1540496X.2018.1524 326

Berger, A., \& Sedunov, J. (2017). Bank Liquidity Creation And Real Economic Output. Journal Of Banking And Finance 81, 1-19.

Berger, A.N, B., C.H.S, K., \& Schaeck, K. (2011). Bank Risk Taking And Liquidity Creation Following Regulatory Interventions And Capital Support. Center Discussion Paper, Vol. 2011-088.

Dusuki, A. (2007). Commodity Murabahah Programme (CMP): An Innovative Approach To Liquidity Management. The 5 Th International Islamic Finance Conference. Malaysia, $3 \mathrm{Rd}-4 \mathrm{Th}$ September 2007. Kuala Lumpur, Malaysia: Monash University.

Faturrahman, A., \& Rusdi, F. (2019). Analisis Faktor-Faktor Yang Mempengaruhi Likuiditas Bank Syariah Di Indonesia Menggunakan Metode Vector Error Correction Model (VECM). Al-Masraf (Jurnal Lembaga Keuangan Dan Perbankan), Volume 4, Nomor 2, Juli - Desember 2019.

Halit, Y., \& Pabuccu, Y. U. (2017). Causes And Solutions For The Stagnation Of Islamic Banking In Turkey. International Journal of Islamic Finance (ISRA), 9 No. 1, 2017, 4361. Doi:10.1108/IJIF

Handayani, \& Abubakar. (2018). Regulasi Pengelolaan Likuiditas Bank Melalui Kewajiban Penerapan Net Stable Funding Ratio (NSFR) Sebagai Upaya Menciptakan Perbankan Yang Sehat. Jurnal Varia Justicia, Vol 14 No (1) 2018 ISSN 2579-5198.
Horvarth, Roman, Seidler, Jakub, Weill, \& Laurent. (2012, July). Bank Capital And Liquidity Creation: Granger Causality Evidence. IOS Working Papers, 318.

Ibe, S. (2013). The Impact Of Liquidity Management On The Profitability Of Banks In Nigeria. Journal of Finance And Bank Management, 1(1), 37-48.

Ichwan, M. C., \& Nafik HR, M. (2016, Februari). Faktor-Faktor Yang Berpengaruh Terhadap Likuiditas Bank Syariah . Jurnal Ekonomi Syariah Teori Dan Terapan, Vol. 3 No. 2, 144-157.

Ismal, R. (2010). Strengthening And Improving The Liquidity Management In Islamic Banking. Humanomics, Vol. 26 No. 1, 2010, $18-$

35.Doi:10.1108/082886610110249 77

Lukorito, Sarah Nabalayo, Willy Muturi 2, Andrew S. Nyang'au, Dennis Nyamasege (2014), Assessing the effect of liquidity on profitability of commercial banks in Kenya, Research Journal of Finance and Accounting www.iiste.org ISSN 2222-1697 (Paper) ISSN 22222847 (Online) Vol.5, No.19, 2014

Khotijah, S. A. (2020). Analysis Of The Effect Of Murabaha Finance In Sharia Banks On The Economic Growth Of Agricultural Sector. Amwaluna: Jurnal Ekonomi Dan Keuangan Syariah, 4(2), 246-259. Https://Doi.Org/10.29313/Amwalu na.V4i2.5432

Ledhem, Mohammed Ayoub and Mekidiche, Mohammed (2020), Economic growth and financial performance of Islamic banks: a CAMELS approach, Islamic Economic Studies, Vol. 28 No. 1, 2020 pp. 47-62, Emerald Publishing Limited, e-ISSN: 2411-3395, p- 
ISSN: $\quad 1319-1616, \quad$ DOI 10.1108/IES-05-2020-0016

Mandala, Ratu Ahdini Magfuroh (2020), INFLATION, GOVERNMENT EXPENDITURE, AND ECONOMIC GROWTH IN INDONESIA Jambura Equilibrium Journal (JEJ), Volume 2. Number 2. July 2020 Pp 109-118, P-ISSN

Mars. (2008). The Study Of The Market And Islamic Banking Depositors Behaviors 2008. PT. Mars Indonesia Jl. Paus 89G Rawamangun, Jakarta.

Mohammad, S. (2014). Liquidity Creation And Liquidity Risk Exposures In The Banking Sector: A Comparative Exploration Between Islamic, Conventional And Hybrid Banks In The Gulf Corporation Council Region, Durham Theses, Durham University. Diambil Kembali Dari Http://Etheses.Dur.Ac.Uk/10890/

Ningsih, W., Badina, T., \& Rosiana, R. (2017). Pengaruh Permodalan, Kualitas Asset, Rentabilitas Dan Likuiditas Terhadap Profitabilitas Bank Pembiayaan Rakyat Syariah (BPRS) Di Indonesia. Akuntabilitas: Jurnal Ilmu Akuntansi, Volume 10 (1), April 2017 (P-ISSN: 1979-858X; EISSN: 2461-1190), 181 - 19.

Noegroho, I. (2014). Manajemen Likuiditas Sebagai Pedoman Kerja Dual Banking System. BALANCED, Economics, Bussines, Management And Accounting Journal., X/ No.19/(ISSN 1693-9352).

Notoatmojo, M. (2018). Analisis Dampak Likuiditas Terhadap Profitabilitas Pada Bank Umum Syariah Di Indonesia Periode 2010-2016. EQUILIBRIUM : Jurnal Ekonomi Syariah, Volume 6, Nomor 2, 2018(P-ISSN: 2355-0228, E-ISSN: 2502-8316), 19 - 41. Diambil Kembali
Journal.Stainkudus.Ac.Id/Index.Ph $\mathrm{p} /$ Equil

Rashid, M., Ramachandran, J., \& Fawzy, T. (2017). Cross-Country Panel Data Evidence Of The Determinants Of Liquidity Risk In Islamic Banks: A Contingency Theory Approach. International Journal of Business And Society, Vol. 18 S1, 2017, 3-22.

Sahyuni, A., \& Wang, M. (2019). Liquidity Creation And Bank Performance Of Syrian Banks Before And During The Syrian War. International Journal Of Financial Studi, 7, 40. Doi:10.3390/Ijfs7030040

Setiawan, Iwan (2017), Peran Perbankan Syariah Terhadap Perekonomian Di Indonesia (Pendekatan Model Var/Vecm), Jurnal TEDC Vol. 11 No. 2, Mei 2017, Halaman 172-178

Setiawan, I. (2019). The Role Of Islamic Banking In The Development Of Economic Sectors In Indonesia. International Journal of Applied Business Research, 1(2), 88-99. Retrieved From Https://Ijabr.Polban.Ac.Id/Ijabr/

Sukmana, R., \& Suryaningtyas, S. (2016). Determinants Of Liquidity Risk In Indonesian Islamic And Conventional Banks. Al-Iqtishad: Jurnal Ilmu Ekonomi Syariah (Journal Of Islamic Economics), Volume 8 (2), July 2016(P-ISSN: 2087-13).

Trenca, I., Petria, N., \& Corovei, E. (2015). Impact Macroeconomic Variables Upon The Banking System Liquidity. Procedia Economics And Finance 32 (2015) 1170-1177.

Zaini, M. (2016). Manajemen Likuiditas Bank : Tarik-Ulur (Trade-Off) Antara Likuiditas Dan Profitabilitas. Iqtishoduna, Vol. 7 No. 1 April 2016, 113-121. 